\title{
Comparison of Mechanical and Tribological Properties of TiCN and CrCN Coatings Depos- ited by CAD
}

Totka Bakalova ${ }^{1}$, Nikolay Petkov ${ }^{2}$, Hristo Bahchedzhiev ${ }^{2}$, Pavel Kejzlar $^{1}$, Petr Louda ${ }^{1}$

${ }^{1}$ Institute for Nanomaterials, Advanced Technologies and Innovation, Technical University of Liberec, Studentská 2, 461 17 Liberec, Czech Republic, E-mail: totka.bakalova@tul.cz, pavel.kejzlar@tul.cz, petr.louda@tul.cz

${ }^{2}$ Central Laboratory of Applied Physics, Bulgarian Academy of Sciences, 61, St. Peterburg Blvd. 4000 Plovdiv, Bulgaria.

E-mail: petkovnik@gmail.com, hristo_bah@abv.bg

The aim of this paper is to compare the mechanical and tribological properties of TiCN and CrCN coatings. These coatings are widely used in industrial applications to improve both friction and wear. They are deposited at the same deposition parameters using an industrial Physical Vapour Deposition (PVD) system. Estimation of the tribology properties is made in a "ball-on-disc" mode, and the wear and wear rates of the coatings and counterbodies are compared. The test study is conducted using a ball made from $\mathrm{Al}_{2} \mathrm{O}_{3}$ with a diameter of $6.350 \mathrm{~mm}$ and a load of $10 \mathrm{~N}$, at room temperature and a humidity of $44 \pm 2 \%$. The mechanical properties are estimated by nanoindentation, a scanning electron microscope and a mechanical profilometer, and the hardness, elastic module, chemical composition, and surface coating morphology are estimated. The scratch test is performed on the coatings using a CETR UMI Multi-Specimen Test System scratch tester device with a progressive load from 2 to $100 \mathrm{~N}$ and speed of $10 \mathrm{~mm} / \mathrm{min}$, according to the ISO EN 1071-3:2005 standard.

Keywords: Cathodic Arc Evaporation, Surface coating morphology, Friction Coefficient, Wear and Wear Rate

\section{Acknowledgement}

The paper was supported in part by the project LO1201 through the financial support of the Ministry of Education, Youth and Sports in the framework of the targeted support of the "National Programme for Sustainability I" and the OPR\&DI project "Centre for Nanomaterials, Advanced Technologies and Innovation" registration number CZ.1.05/2.1.00/01.0005.

\section{References}

[1] SU, Y. L., LIN, J. S., (1993).Wear 170, 45.

[2] GAHLIN, R., BROMARK, M., HEDENQViST, P., HOGMARK, S., HAKANSSON, G. Ž. (1995). Surf. Coat. Technol., 76, 174.

[3] NAVINSEK, B., PANJAN, P. (1993), Surf. Coat.Technol., 59, 244.

[4] ALMER, J., ODEN, M., HAKANSSON, G. (2001). Microstructure, stress and mechanical properties of arc-evaporated Cr-C-N coatings. Thin Solid Films, 385, 190-197.

[5] ČEKADA, M., MAČEK, M., MERL, D. K., PANJAN, P. (2003). Thin Solid Films, 433, p. 174.

[6] ČEKADA, M., PANJAN, P., MAČEK, M., ŠMID, P. (2002). Surf. Coating Technol., 151-152, p. 31.

[7] WU, Z. L., LIN, J., MOORE, J. J., LEI, M. K. (2009). Surf. Coating Tech., 204, p. 931.

[8] CHOI, E. Y., KANG, M. C., KWON, D. H., SHIN, D. W., KIM, K. H. (2007). J Mater Process Tech, 187-188, p. 566.

[9] PENGFEI, H., BAILING, J. (2011). Vacuum 85, p. 994.

[10] TONG C. Y., LEE J. W., KUO C. C., HUANG S. H., CHAN Y. C., CHEN H. W., et al. (2012). Surf Coat Technol, dx.doi.org/10.1016/j.surfcoat.2012.01.009.

[11] HSIEH, J. H., TAN, A. L. K., ZENG, X. T. (2006). Surf. Coat. Technol., 201, 4094.

[12] BARAVIAN, G., SUlTAN, G., DAMOND, E., DETOUR, H. (1995). Surf. Coat. Technol., 76/77, 687.

[13] BAKALOVA, T., et al. (2016). Influence of Coating Process Parameters on the Mechanical and Tribological Properties of Thin Films, Defect and Diffusion Forum, Vol. 368, p. 59-63.

[14] BULL, S. J., BHAT, D. G., STAIA, M. H. (2003). Surf. Coat. Technol., 163-164, 507.

[15] HUANG, S. W., NG, M. W., SAMANDI, M., BRANDT, M. (2002). Wear 252, 566.

[16] HOVSEPIAN, P. EH., EHIASARIAN, A. P., DEEMING, A., SCHIMPF, C. (2008).Vacuum, 82, 1312. 
[17] GERTH, J., LARSSON, M., WIKLUND, U., RIDDAR, F., HOGMARK, S. (2009). Wear 266, 444.

[18] JAROS, A., SEDLÁK, J., FIALA, Z., CHLADIL, J., DVORACEK, J. (2016). Investigation of the Influence of PVD Coatings Deposited on HSS Milling Cutter, In: Manufacturing Technology, Vol. 16, No. 3, p. 506 - 512, ISSN 1213-2489.

[19] CAROU, D., ŘEHOŘ, J., MONKA, P., VILČEK, I., HOUDKOVÁ, Š. (2015). Insights for the Selection of the Machining Parameters in the Turning of Difficult-To-Cut Coatings, In: Manufacturing Technology, Vol. 15, No. 3, pp. 295 - 303, ISSN 1213-2489.

[20] BAKALOVA, T., et al, (2016). Biocompatibility of Surfaces of TiCN Thin Films, LMP 2015.Churerstrasse 20, CH-8808 Pfaffikon, Switzerland: Trans Tech Publications Inc., 2016. p. 64 - 68. ISBN 978-303835720-9, ISSN 10120386.

[21] LEYLAND, A., MATTHEWS, A. (2000), Wear 246, p. 1 - 11.

[22] BAKAlOVA, T., PETKOV, N., CHOLAKOVA, T., KAVÁN, FR., BAHCHEDZHIEV, Hr., Mechanical Properties of Titanium-Aluminium base nanomultilayer coatings, In: Manufacturing Technology- In press.

[23] CARVALHO, P. (2008). Development of new decorative coatings based on zirconium oxynitrides, Ph.D. Thesis, University of Minho, http://hdl.handle.net/1822/8949, Portugal.

[24] BAKALOVA, T., et al. (2015). Nanoadditives $\mathrm{SiO}_{2}$ and $\mathrm{TiO}_{2}$ in Process Fluids, In: Manufacturing technology, Vol. 15, No.4, p. 502 - 508, ISSN 1213-2489.

[25] SINGH, K., LIMAYE, P. K., SONI, N. L., GROVER, A. K., AGRAWAL, R.G., SURI, A.K. (2005). Wear, 258, 1813. 